\title{
Amenity Migration, Exurbia, and Emerging Rural Landscapes: Global Natural Amenity as Place and as Process
}

Kirsten Valentine Cadieux

University of Minnesota - Twin Cities

Patrick T. Hurley

Ursinus College, phurley@ursinus.edu

Follow this and additional works at: https://digitalcommons.ursinus.edu/environment_fac

Part of the Environmental Policy Commons, Environmental Studies Commons, Nature and Society Relations Commons, Other Political Science Commons, Place and Environment Commons, and the Urban Studies and Planning Commons Click here to let us know how access to this document benefits you.

\section{Recommended Citation}

Cadieux, Kirsten Valentine and Hurley, Patrick T., "Amenity Migration, Exurbia, and Emerging Rural Landscapes: Global Natural Amenity as Place and as Process" (2011). Environmental Studies Faculty Publications. 2.

https://digitalcommons.ursinus.edu/environment_fac/2 
Published in GeoJournal, 2011, Volume 76, Issue 4 (Pages 297-302)

\title{
Amenity Migration, Exurbia, and Emerging Rural Landscapes: Global Natural Amenity as Place and as Process
}

\author{
Kirsten Valentine Cadieux ${ }^{1}$ and Patrick T. Hurley ${ }^{2}$ \\ ${ }^{1}$ Department of Geography, University of Minnesota \\ 267 19th Avenue South, Minneapolis, MN 55455, USA \\ e-mail:kvcad@post.harvard.edu \\ ${ }^{2}$ Environmental Studies Program, Ursinus College, \\ P.O. Box 1000, Collegeville, PA 19426, USA \\ e-mail: phurley@ursinus.edu
}

Trends of amenity migration and exurbanization are changing the ways many rural landscapes around the globe are used, imagined, and transformed. The articles in this special issue examine these trends in diverse ways, providing a 'state of the research' view of amenity migration and exurbia from the perspectives of rural and cultural geography and political ecology. This research engages difficult questions about increasingly common land uses in high amenity rural and exurban areas and the environmental ideals and policies that are associated with these places. The assembled articles suggest that environmental governance and ideology may be inadequately aligned with diverse needs and desires in the many places experiencing exurbanization. The rural is still too often thought of as removed from modern globalized networks of mobility and representation, and rural governmental institutions facing exurbanization and amenity migration are often unequipped to grapple with the multiple competing interests that constitute diverse and changing rural agendas. By focusing mainly on protecting particular rural landscape attributes or specific ecological attributes, or on facilitating urbanization processes and development opportunities, environmental management practices may often miss opportunities to engage with the complex mixing of urban and rural and to facilitate dialogue across competing perspectives.

The geographical research in this special issue helps to elucidate the context and causal structures associated with the complex relationship between urban and rural, particularly in regions experiencing dispersed urbanization and exurban landscape change. This research considers the breadth and diversity of conditions and locations in which amenity migration is reworking rural landscapes, as well as the politics that accompany and result from these changes. This focus highlights the ways that the urban and the rural are closely intertwined. For example, urbanizing regions can be particularly susceptible to changing trends in land economics and environmental management practices, and exurban environmental policies and representations are often strongly influenced by urban imaginaries and ideologies of rural nature. Increasingly global in both extent and character, the amenity of rurality has played a volatile role in dispersed urbanization over the past century.

Early twentieth century patterns of migration and residential land use, characterized by a shift from rural to urban dwelling in industrialized countries, were to some degree reversed in past decades by first-world urbanites' attempts to reclaim the rural. As travel and communications technologies have transformed the meaning of distance, the rural retreat - that prized antidote to the urban and the modern condition of perceived alienation from nature - has edged closer to the reach of privileged urbanites around the world. However, the volatility of housing markets has left many urbanizing rural regions and sites of amenity migration uncertain about residential land use trends, and called into question 
accepted projections and rationales for the rate and shape of urbanization. At the same time that almost two percent of U.S. households are under foreclosure and countless exurban residential land parcels are tied up as 'toxic' securities, Silicon Valley executives continue to telecommute from Argentinean haciendas, some Britons jet across the channel for week-end retreats at Slovakian or Provencal country cottages, North American celebrities take shelter on Antipodean sheep stations, and a stream of other migrants claim their own parcels of rural paradise. These migrations, acquisitions, and even uncertainties about the shifting fortunes of the real estate industry and global trends of economic depression all contribute to a reconfiguration of rural communities and landscapes. In addition, as the rural aesthetics of gardening and outdoor lifestyle take their places in modern urban and suburban landscapes, exurban trends of valuing the rural in particular ways that emphasize their value as sites of landscape consumption may also be affecting mainstream ideals for residential land use in far more places than those sought out as amenity destinations or designated exurban.

The seven articles in this collection explore the forces of amenity migration and exurbanization as they are transforming the rural landscape, focusing on the implications of how residents' desire to live in exurbanizing rural landscapes complicates rural environments, governance, and resource management. These articles engage the phenomenon of the amenity-driven transformation of rural landscapes in terms of: environmental and governance issues; the formation and performance of rural identities; land and resource management challenges associated with residential amenity landscapes; and the ways that existing institutions, management regimes, and regulations are engaging these issues. Presenting a range of synthetic reviews of the central topics of exurbia and amenity migration and analyses of specific cases, the article authors draw on a broad range of literatures and case studies from the U.K., New Zealand, Canada, and different regions within the U.S. - moving beyond more characteristic analyses of the American West or of megalopolitan exurbia - to explore the problem of how to define, study, and manage contemporary rural landscape processes within the context of amenity migration and exurbanization. The three commentaries at the end of this special issue section discuss specific contributions of the gathered articles; in addition, two broad themes characterize these articles' contribution to exurbia studies. First, the articles consider together the increasingly global dimensions and ramifications of residential mobility and migration related to natural landscape amenity. Second, the gathered contributors approach exurbanization both as a concept and as a process. We briefly describe these two themes in relation to articles in this special issue. Because the first two articles in this special issue place these themes within extensive reviews of existing literature on exurbia and amenity migration, we do not provide an overview of previous literature here; rather, we concentrate on discussing the ways these papers add to previous work on urbanization and the urbanrural relationship in a few exciting ways.

\section{Globalizing natural amenity}

At the turn of the twenty-first century, baby boomers and others benefitting from rising economies directed capital into places that would provide not only promising investments but also improved quality of life - as defined by a particular aesthetic of high amenity rural and natural 'lifestyle' landscapes. Natural- and rural-appearing lifestyle landscapes seem to be central to both exurbia and amenity migration. Consequently, considering exurbia from an academic perspective in terms of natural and rural ideals - along with the ecological, political, and economic practices of amenity migrants that these ideals motivate- helps identify commonalities in the ways that amenity migrants perceive and interact with their environments. Exurban lifestyle landscapes that have often been associated with the peri-metropolitan fringes of major U.S. cities and traditional far-flung lifestyle hinterlands in the western U.S. have become an international — and transnational — phenomenon. 
Research on amenity migration into rural areas has documented its increasingly global character. Understanding this international quality of amenity migration helps us understand some key features of the phenomenon; we highlight two. The housing ideology of the single-family home on its own property associated with the American Dream has spread far beyond the borders of the first world suburbs with which it is often associated - both to locations where it has been reproduced by expatriate exurbanites, such as in Guatemala, and also to rapidly changing metropolitan regions, for example, in China. This residential landscape ideology was very influential in driving the real-estate and associated mortgage securitization bubble that had such dramatic effect on global capital markets - in addition to the cumulative impacts related to the increased consumption, costs, and environmental and social effects of larger, more dispersed houses.

In addition, studying the features of amenity migration in different places also shows how much the phenomenon is tied to economic trends that are global in scope. As the mobility of people and capital facilitate patterns of multiple residency, amenity migration is reshaping local landscapes, and global economic dynamics are ever more visibly reflected in local property dynamics. Several of the articles consider exurbanization in relation to broader rural restructuring, and to what happens to land as agriculture and forestry production practices change. It is particularly in the struggles between larger economic forces and local agency that the comparative approach to exurban issues provides purchase on wider dynamics that transcend particular places - and the capacity of local infrastructures.

In The local politics of the global countryside, Michael Woods describes how rural places are constructed, represented, and constituted in globalizing contexts. His analysis pays particular attention to the ways these negotiations involve both local and global actors, to the importance of international tourism in relation to amenity migration, and to the way that local politics both reflect and respond to global processes. Woods also notes the continuing significance of the state in mediating the construction of countrysides (both global and local), a theme also taken up by Alister Scott, James Shorten, Rosalind Owen, and Iwan Owen in What kind of countryside do the public want. Several of the articles examine the ways that conflicts in today's sites of amenity migration may be shaped by longstanding historical links to global capital flows and migration. In Dodging alligators, rattlesnakes, and backyard docks, Patrick Hurley and Angela Halfacre describe, for example, discourses of cultural protection and natural resource conservation are shown to have important ties to West Africa. And in Democracy or expertise?, Tom Young explores competing discourses and legitimacy frames for different land uses related to shifts in longstanding and complex governance and access regimes for forestlands and in global commodity markets, land ownership patterns, and recreation ideologies.

\section{Exurbia as place and as process}

Understanding the emergence of exurban amenity landscapes and the ways such landscapes are addressed in planning and policy - as well as how they are experienced and aspired to by residents and potential residents - requires the application of a broad and ecumenical approach within exurbia studies. But there are significant conceptual and logistical challenges involved in studying exurbia. Difficulties face both researchers and participants in the process of learning about the competing interests and understandings of the different actors involved in exurbanization processes, about the emerging and the declining uses of exurbanizing land, and about the interactions between different actors - particularly around the consumption of amenity landscapes and the natural resource economies that help produce these landscapes. In addition, both globalizing phenomena and socio-ecological landscape changes require both local and synoptic approaches. Also contributing to and driving the emerging research agenda reflected in this special issue are growing interests in governing rural landscapes and in producing a more diverse set of social and economic values via rural landscapes and 
emerging rural-urban landscape hybrids. The policies that produce and accompany exurbanization often struggle to keep up with the rapid changes in land use that exurbanization and amenity migration entail, given the complex circulation of people, new ideas, and intensification of capital from new sources among different sites and across multiple scales.

As the broad review articles by Laura Taylor-No boundaries - and by Hannah Gosnell and Jesse Abrams - Amenity migration - demonstrate, the majority of literature on exurbanization has been oriented toward assessing policy and management considerations, whether in terms of exurbanization's ecological impacts or its infrastructural needs. The focus of this literature has been on exurbanization as a process that transforms landscapes in ways that produce a particular kind of place, including assessing the location and composition of exurban settlement as well as their influence on ecological relationships. However, as Taylor and Gosnell and Abrams further demonstrate, the dominant paradigms within this work concentrate either on studying exurbanization as a process of that is constituted through particular configurations of services, spatial distributions, and demographics, or on studying exurbia as an experienced place, whose residents' motives, reactions, and plans can be studied. Although both reviews identify exceptions, these process and place strands have not often been systemically integrated, despite frequent explicit connections to the cultural landscape philosophy that Taylor details, and its emphasis on such integration. Building on recent work in political ecology and rural and cultural geography, this special issue extends the focus of exurban scholarship by using the perspective of critical cultural geography to help develop examinations of exurbia as both place and as process. The articles' authors integrate disparate strands of research on exurbia: examination of environmental impacts and research on the landscape characteristics that attract amenity migrants. By bringing together these two strands using cultural geography approaches, the authors position themselves to address questions of why different actors experience tension over particular forms of exurban environmental management, how regional and international amenity migration is reproducing exurbs on a global scale, and the drive behind new forms of governance, conservation, and planning practice in exurbanizing regions.

Although reconciling disparate methods and epistemologies is difficult (not least because the different strands of research are developing in fairly disparate lineages), understanding exurbanization as a complex phenomenon is helped considerably by combining or juxtaposing different conceptual and theoretical ways of understanding exurbia and amenity migration. This collection of articles represents an important addition to the body of exurbia studies in geography, addressing gaps in our understanding of the motives of exurban actors and their engagement with shifting management regimes, the natures that produce landscape amenity, and the social and policy interfaces of exurbanization. Addressing these knowledge gaps helps to balance the usefulness of demographic and morphological precision in specific exurban definitions with the potential for comparison and excavations of changing power dynamics offered by broader analyses of exurbanization.

Broader perspectives help integrate different modes of geographical investigation. In doing so, researchers can move from the consideration of broad themes to the development of more systematic research programs that 1) facilitate dialogue between academics and practitioners-pointing to ways that theoretically driven questions can provide new insights for policymakers - and 2) grapple with crossing the methodological and theoretical boundaries that derive from disciplinary and subdisciplinary concerns. This is particularly true when confronting the standards for defining what count as meaningful and testable variables as well as knowable exurban characteristics.

Applying insights from political ecology to the literature on amenity migration in regions not often considered within the exurban or amenity migration literatures, the following articles demonstrate the potential for overlaps between new forms of environmental management and historical land uses. 
They further highlight the perhaps contrasting possibility for disconnects that derive from divergent landscape preferences and understandings of landscape history among different participants in exurbanization whose perspectives and discourses face difficult barriers to communication and cooperation. In addition, the articles repeatedly emphasize a series of key relationships that are coming to characterize exurbanization as process and place: between the commodification of domestic rural landscapes and global patterns of capital investment and commodity markets; between the role of individual preferences, decisions, and behavior and the economic, political, and social structures that make practices possible, desirable, and socially acceptable; and between the implications of emerging carbon and energy initiatives on the justifications for particular land uses and the social justice dimensions of resource access and distribution.

The authors in this special issue take up these themes in different ways. Hannah Gosnell and Jesse Abrams take on 'natural amenities,' exploring the multiple ways in which this concept has been conceptualized, theorized, and documented by different fields of scholarship relevant to the study amenity migration. Their review highlights key impacts of the process of amenity migration, the emerging challenges within the fields that study it, and pressing research needs. Approaching similar issues from the perspective of research on exurbanization, Laura Taylor calls for a new kind of research that takes into account the cultural experience of landscape in ways that help us better understand urban dispersion, its experience by its participants, and the landscapes it produces. Taylor points out key issues relating to the limits presented by data and statistical analyses that seek to spatially represent exurbia and considers the ways these data limits restrict the types of questions that can be asked about exurbanization. Woods further demonstrates the importance of understanding the relationship between place and process by showing how particular concepts of amenity and landscape have been materialized and politicized in the specific case of Queenstown, New Zealand.

Focusing on an empirical case study of tensions between valorization of urban containment and exurban expansion in Competing discourses of nature in exurbia, Valentine Cadieux examines the role that nature plays in the changing political economy and ecology of exurbia. She highlights the processes that produce, regulate, and consume nature in exurbia, and creates an analytical framework for more actively contextualizing how 'nature' is used in discourses relating to exurbanization and amenity migration. In a parallel fashion, Patrick Hurley and Angela Halfacre highlight the role of overlapping but disconnected conservation discourses, pointing to the implications of amenity migration for the livelihoods of long-time basket-makers in the South Carolina Lowcountry. Tom Young further explores the importance of dialogue across competing perspectives and often incommensurate scales in his case study of the process of multi-scalar forest conservation and access governance in Vermont. Taking a bottom-up perspective, Alister Scott and colleagues focus on difficulties in reconciling place and process, and in developing adequate methods for delivering policy results and effectively maintaining community participation in community-led rural planning policy in the United Kingdom. Their work suggest that although there is a relatively good rapport between what policy strives to achieve and what communities actually want, tensions between national and local politics and stakeholder power relations complicate the on-the-ground efforts arising from "visioning" processes. These tensions, as exurban policy makers and researchers attest, are central complicating factors for both research and policy.

\section{Further questions}

This collection of articles and commentaries by Peter Nelson, Nathan Sayre, and Peter Walker were originally presented at the Denver meetings of the Association of American Geographers. The two review articles and the commentaries help to place the conversation about the themes above in the 
broader context of current work on exurbanization, amenity migration, and changing rural landscapes, and particularly to highlight the way these papers help build foundations for extending research on 'amenity' and 'exurbia,' building better connections between work conducted at varying spatial scales, using different methodologies, and integrating complementary perspectives on different aspects—such as socio-spatial, ethnic, and ethical aspects — of the phenomena of exurbanization and amenity migration. Many linkages still remain to be made between the different strands of research to which we refer - and to those to which we aspire. In particular, scholars of exurbia continue to grapple with the difficulties of reconciling qualitative and quantitative methods used (and topic areas focused upon) in the study of exurbanization and amenity migration by cultural geographers and political ecologists.

We see a number of key questions that remain largely unanswered and that would greatly improve our understanding of these processes and places. Importantly, these include both methodological and social-economic questions that remain to be thoroughly explored. For example, how can we best measure, assemble, and integrate data on the rates, volumes, and patterns of amenity property acquisition world-wide? What kinds of ecological trajectories (not just impacts), labor and migration patterns (including secondary migration that services amenity migration), and emerging social relations are associated with the rural amenity property boom? How can we assess the role of ongoing agricultural restructuring in expanding the amenity frontier? To what extent are amenity consumption and resource production being integrated and what ecological and social trade-offs are involved in the substitution of extractive industries with amenity consumption? How will current models of exurbanization hold up under the simultaneous extreme volatility of commodity and property markets, particularly given contemporary global economic conditions? How will amenity property patterns be affected by the emerging landscape of carbon crediting?

Although these questions extend far beyond the considerations of the following articles, they have sparked ongoing research conversations about how to apply the insights gathered here: about the global dimensions of amenity landscape transformation and the need to combine place- and processoriented methods to study manifestations of exurbia and amenity migration across regions and also across methods. These broader contextual questions are crucial to understanding commonalities across different exurban manifestations and locations, especially in the context of growing uncertainty about the future of residential settlement patterns under conditions of economic instability.

\section{Acknowledgements}

We thank the scholars - included in this special issue and otherwise - who participated in the Amenity Migration, Exurbia, and Emerging Rural Landscapes sessions, and who have participated in the related exurbia panels since, at the Association of American Geographers meetings. We are grateful to all of the reviewers whose thoughtful commentaries improved the articles, and particularly to Julia Hobson Haggerty, who played a central role in organizing the sessions and this journal issue, and to Laura Taylor and Tom Young, who have enthusiastically helped carry on the conversation since. We look forward to continued conversations. 